\title{
GEODESY
}

\section{UDC 528.22}

\author{
K. R. TRETYAK, I. BRUSAK \\ Department of Higher Geodesy and Astronomy, Lviv Polytechnic National University, 12, S. Bandera Str., Lviv, 79013, \\ Ukraine
}

http://doi.org/10.23939/jgd2020.01.005

\section{THE RESEARCH OF INTERRELATION BETWEEN SEISMIC ACTIVITY AND MODERN HORIZONTAL MOVEMENTS OF THE CARPATHIAN-BALKAN REGION BASED ON THE DATA FROM PERMANENT GNSS STATIONS}

The problem of earthquake prediction, as well as its interrelation with horizontal movements of the Earth's crust has not still been solved. The purpose of the work is to establish a possible correlation between generalized parameters of horizontal movements of the Earth's crust and seismicity. The Carpathian-Balkan region in connection with frequent and spatial differentiation of earthquake activity and well-known geological structures is chosen as a field for the research. Methods. Based on the data of permanent GNSS stations in 20102019, the horizontal velocities and deformations of the Carpathian-Balkan region are analyzed, as well as the maps of fields of the annual distribution of dilatation are added. The annual generalized parameters of seismicity for separate blocks are calculated from the data of seismological stations. Based on the spatial analysis of horizontal deformations and generalized seismicity, the correlations between absolute values of dilatation and semi-major axis of ellipse of scattering earthquake epicenters are established. As the results, the authors demonstrate some territories covered by the annual high degree of correlative connection between semi-major axis of the ellipse of scattering earthquake epicenters and absolute values of dilatation. The biggest correlative zone includes the Rhodopes, a subduction zone between Nubia and Europe tectonic units. The territory of stable correlations also coincides with Vrancea. The research suggests that the interconnection between horizontal deformations and generalized seismicity occurs only in subduction zones where there are both intense seismic activity and regular crust deformations. This is confirmed by the appearance of correlation zones which are located along one side of the active faults.

Key words: horizontal deformations of the Earth's crust, permanent GNSS stations, earthquakes, interrelation between seismicity and movements of GNSS stations.

\section{Introduction}

The purpose of the work is to establish a possible interrelation between generalized parameters of horizontal deformations of the Earth's crust and seismic activity.

The Carpathian-Balkan region is chosen for the research. Firstly, the region includes different zones based on the magnitude, depth and frequency of the earthquake occurrence. Secondly, the geological structures as well as modern horizontal deformations of the region are well-researched.

The problem of earthquake prediction as well as its interrelation with horizontal movements of the Earth's crust has not still been solved. That is why in the last decade some detailed studies on this issue have been conducted. Often the works of scientists show different results. For example, regarding the study of the Apennine Peninsula, Riguzzi, et al., [2012] conclude that in areas with minimal deformation of the territories there is the highest probability of earthquake occurrence. In contrast, later studies of the same region did not reveal such interrelation, because both small and large-magnitude earthquakes belong to different zones of horizontal deformations without any general dependence. [Cenni, et al., 2015].

There are some studies that consider the modeling of modern tectonic deformations according to GNSS data with spatial maps. The epicenters of the earthquakes that occurred are added on these maps. This method can visually single out potentially seismically dangerous zones in different regions of the world: Western Canada [Mazzotti, et al., 2011], Northern Caribs [Benford et al., 2012], Iberian Peninsula [Pena Castellnou, 2018]. Some mathematical interrelations between deformations and seismicity parameters are also established. For instance, Gulal, et al., [2016] analyze more than 2,000 earthquakes with the magnitude above 4 over the 100year period in southern Anatolia (Turkey) and identify certain mathematically correlated regions, in which earthquakes of magnitude 6 and above are likely to occur over the next 25 years. Although the selection 
of regions was based on the parameter $b$ by the Kaltek method, which is more related to the nature of the earthquake, the constructed maps show that areas of increased risk of earthquakes correspond to the regions where the modern horizontal deformations are significant. Kao, et al., [2018] demonstrate correlations between crustal deformations and weak injection-induced earthquakes in Western Canada. To do this, the study area is divided into squares with sides of $20 \mathrm{~km}$. In these zones the interrelation between the moment of earthquakes and tectonic moments of the region is noticed. As a result of the investigations, the authors claim that modern tectonic deformations are a major cause in the occurrence of injection-induced earthquakes.

Overall, the recent studies show that geodetic monitoring together with the detailed understanding of the modern tectonic structure of the territory could be a ground for identifying the areas where there is a high probability of an earthquake occurrence.

The interrelation between seismic activity and vertical movements of the Earth's crust for Europe has been established in [Tretyak \& Romaniuk, 2014]. For the Carpathian-Balkan region, a close correlation between these parameters has been established in the area covering the Dinarides and the adjacent part of the Adriatic coast. The question arises: are there corresponding correlations between seismic activity and horizontal deformations of the Earth's crust too? To get an answer to this question, this research has been performed, which is, in fact, a continuation of the work done by [Tretyak \& Romaniuk, 2018] using similar methods.

\section{Description of the research region Tectonic features of the region}

To analyze the interrelations between modern horizontal deformations of the Earth's crust and seismic activity, the territory the Carpathian-Balkan region is chosen. It is covered by a dense network of GNSS stations and has a significant territorial differentiation of seismic activity as well.

The region includes the Pannonian Basin, the Carpathians, the Balkans, the Rhodopes, the Dinarides, the Hellenides and the Southern Alps, (Fig. 1). The tectonic structures of the region are studied in detail as well as their modern deformations [Caporali, et al., 2009; Meyer, 2011; Nagel, et al., 2011; Jouanne, et al., 2012; Faccenna, et al., 2014; Handy, et al., 2019].

The fault between the Eastern European platform and the Carpathians and the deformations caused in the Southern and Eastern Carpathians are analyzed in detail [Van der Hoeven, et al., 2005; Caporali, et al., 2009] meanwhile Pospisil, et al., [2019] and Gintov, et al., [2015] demonstrate verification of the tectonic model of the Carpathian-Pannonian region and the zone with a possible risk for earthquakes based on the dynamics of the lithosphere, geophysical, and geodetic data.
A new tectonic and geodynamic model was constructed for the Vrancea seismogenic zone, within which two regional transcurrent faults were identified. [Ioane \& Stanciu, 2018].

The study of the geodynamics of Western Bulgaria, based on the seismological and geodetic data, reveals horizontal deformations in the north-south direction which naturally correspond to the normal faults in the region. [Kotzev, et al., 2006].

Research of Macedonia's regional geodynamics shows that its territory is moving to the south along with the part of Bulgaria, comparatively to stable Europe. [Burchfiel et al., 2006].

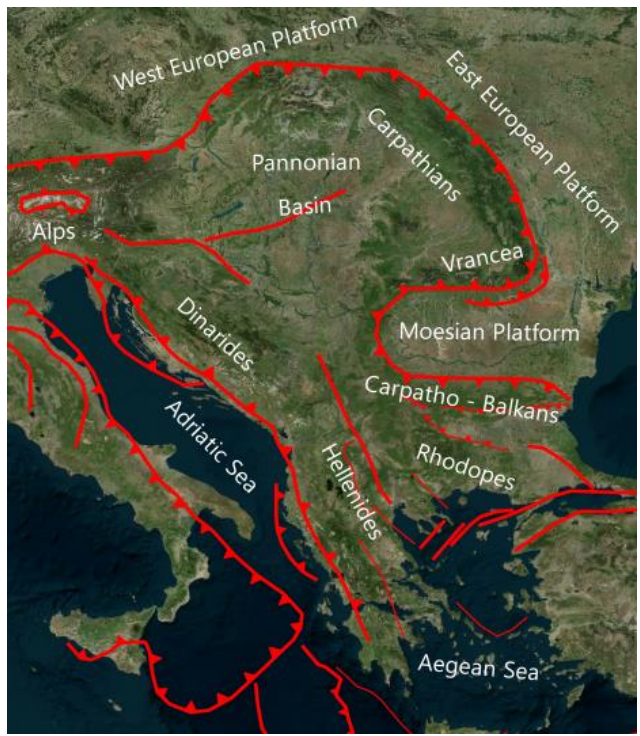

Fig. 1. Major faults and structures of the Carpathian-Balkan region

(based on [Caporali, et al., 2009; Faccenna, et al., 2014; Handy, et al., 2019]

Another major fault is located between the Adriatic Sea and the Dinarides. The Adriatic plate moves as a whole block to the north-east with the velocity equals $4 \mathrm{~mm}$ per year [Altiner et al., 2006]. The Dinarides undergo major deformation changes where smaller blocks with different annual velocities are distinguished. GNSS stations calculated the current deformations of Albania. The research clearly indicates that the same deformation field affects the Western Balkans and the Greek, Macedonian and Bulgarian zones, and the main Shkoder-Peja fault NESW, which is the boundary between the Dinarides and Albanides. [Jouanne, et al., 2012]. Vrabec, et al., [2006] determine the tectonic style of Slovenia and show active deformations along the Periadriatic fault according to GNSS data.

The tectonic structure of the Balkan Peninsula is a complex unit since in the western part there is one large fault on the border with the Adriatic and other two are in the south and east in the Aegean Sea. Thus the territory of Greece is characterized by the most significant horizontal deformations of the central part, 
compressions in the southern and southwestern part, and stretchings in the northwestern part of the peninsula. [Hollenstein, et al., 2008; Chousianitis, et al., 2013]. Significant deformations are observed on the islands in the Adriatic Sea and along the northern fault in the Aegean Sea. [Grenerczy, et al., 2005]

The paper [Caporali, et al., 2009] is the important work for understanding the modern geodynamic model of the whole block that consists of the Alps, the Carpathians, the Pannonian Basin, the Dinarides, and the Balkans in general. Using the data of seven permanent GNSS networks, the research defines the modern horizontal movements of the tectonic units. The detailed analysis is given to crust velocities in the region which include Transylvania, the Southern Carpathians, the Aegean Sea, and Albania. The whole block of Macedonia, Western Bulgaria and Romania undergoes slow movement to the south-south-west.

The Carpathian-Balkan region is located in an important segment of the Alpine-Himalayan orogenic belt and consists of tectonic elements of various scales. The region is the result of the evolution of the Tethys Ocean, which existed between the continental plates of Eurasia (Europe) and Gondwana (Africa) and is represented by geological units formed from the Precambrian and Mesozoic periods. From the Gondwana side, it is represented by the Outer Dinarides, the Dalmatian-Ionian zone, and the Adria microplate, which are mainly formed from the Paleozoic to the Mesozoic.

Complex geological structure and tectonic diversity of the Carpathian-Balkan region are an excellent testing ground for the study of modern horizontal crust deformations.

\section{Seismicity of the region}

The seismic activity does not spread evenly in the region. There are territories with high seismic activity and strong earthquakes (Vrancea, the Dinaric Alps, the Balkan Peninsula), as well as territories where mostly weak earthquakes with lower frequency take place (Pannonian Basin, the Eastern Carpathians).

Vrancea is the most seismically active zone in the Carpathians. This zone is quite narrow $(40 \times 60 \mathrm{~km})$. It is the result of a collision between Africa and Eurasia tectonic units. The deepest earthquakes in the entire territory of the Carpathians with a high magnitude occur exactly in Vrancea. To date, this area is studied well. There are several geodetic and geophysical chains, special simulations of earthquakes, as well as models for earthquakes prediction [Ismail-Zadeh, et al., 2012; Pospisil, et al., 2019; Ioane \& Stanciu, 2018].

Along the west coast of the Balkan Peninsula there is a zone of high activity of strong earthquakes. The local seismicity is the result of a complex geological structure associated with the continental subduction of the Adriatic microplate below Eurasia. [Pearce, et al., 2012; Halpaap, et al., 2018]. Bocchini, et al., [2018] considered in detail the processes in the Hellenic Subduction Zone, by refining the geometry of the
Nubian plate down to $150-180 \mathrm{~km}$ depth, using the located hypocenters from the catalogs of global and local seismicity.

There are three active seismic zones in the Dinarides: the Adriatic coast, the zone around Zagreb, and the Banja-Luka fault region. Spatial distribution of epicenters and focal depths, analysis of the macroseismic field, and the solution of focal mechanisms for several smaller events indicate a constant reduction of the internal Dinarides [Ustaszewski, et al., 2014].

Summarizing the foregoing, the horizontal defomations caused by complex kinematics of the tectonic units and the presence of zones with different seismic activity give the opportunity to consider the Carpathian-Balkan territory as a good field for finding the interrelations between these two phenomena.

\section{The purpose and objectives of the research}

The main purpose of the research is to consider the velocity field of horizontal displacements of the Earth's crust determined from long-term GNSS measurements in the Carpathian-Balkan region as well as generalized parameters of seismic activity to their further prediction.

The following tasks are set in the research:

- to study the annual deformations caused by modern horizontal movements of the Earth's crust in the Carpathian-Balkan region according to long-term GNSS measurements in 2010-2019 years.

- to establish a possible interrelation between the values of the generalized criteria of the field of horizontal deformations of the Earth's crust and seismicity in the Carpathian-Balkan region.

\section{Data \\ Data of permanent GNSS stations}

The initial data for the study of modern geodynamic processes in the region are the final daily solutions of permanent GNSS stations in the coordinate system IGS-2014 from 2010 to 2019, calculated by Nevada Geodetic Laboratory using GIPSY-OASIS-II software [Blewitt et al., 2018].

The study used data from 173 permanent GNSS stations, and their annual number is shown in Fig. 2.

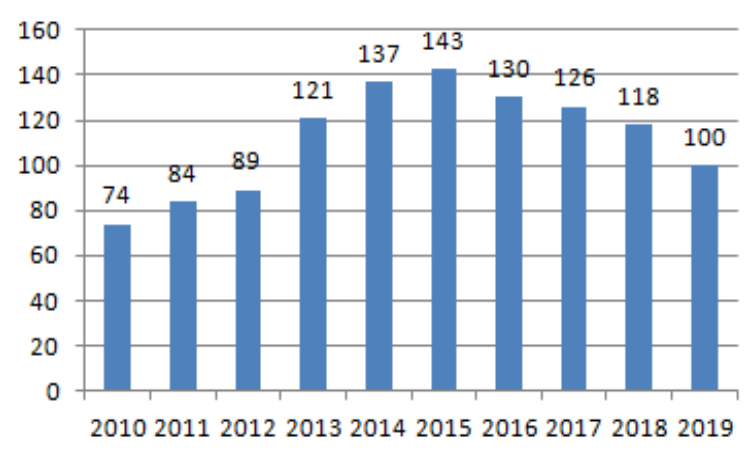

Fig. 2. The annual number of permanent GNSS stations used in the study during 2010-2019 
The selection of GNSS stations was performed under the condition of at least 3 years of continuous operation with a minimum annual number of 200 daily data. In addition, 8 stations were removed from the data list, as they are located at a distance of 1 to $20 \mathrm{~km}$ from several other stations and may lead to inhomogeneity in the spatial distribution of network stations, which may deform the final results of the study. To avoid an error associated with changing the GNSS antennas at permanent stations, appropriate time series corrections were introduced for 45 GNSS stations [Tretyak \& Romaniuk, 2014; Siejka, 2010].

The decrease in the numbers of stations from 2016 to 2019 is mainly due to a lack of a sufficient number of the data (at least 200 final daily solutions per year).

The standard deviation of the coordinates of the final daily solutions in latitude or longitude is equal to 0.6-1.0 mm. To study the horizontal deformations of the Earth's crust, we use the annual velocity of GNSS stations $V_{N}$ in the northern and $V_{E}$ in the eastern directions, which are determined from the solution of linear equations, according to the annual time series. The use of average annual velocities $V_{N}$ and $V_{E}$ allows excluding the influence of seasonal factors.

Table 1

\section{Part of average regional horizontal velocities of permanent GNSS stations in 2019}

\begin{tabular}{|c|c|c|c|c|c|}
\hline \multirow{2}{*}{ № } & \multirow{2}{*}{$\begin{array}{c}\text { The } \\
\text { name } \\
\text { of }\end{array}$} & \multicolumn{4}{|c|}{ Regional Velocity and its standard } \\
& $\begin{array}{c}\text { GNSS } \\
\text { station }\end{array}$ & $\begin{array}{c}\mathrm{V}_{\mathrm{B}}, \\
\mathrm{mm} / \\
\text { year }\end{array}$ & $\begin{array}{c}\mathrm{m}_{\mathrm{VB}}, \\
\mathrm{mm}\end{array}$ & $\begin{array}{c}\mathrm{V}_{\mathrm{L}}, \\
\mathrm{mm} /\end{array}$ & $\begin{array}{c}\mathrm{m}_{\mathrm{VL}}, \\
\text { year }\end{array}$ \\
\hline 1 & ABIU & 3.5 & 1.7 & 4.7 & 1.3 \\
\hline 2 & BACA & 3.0 & 1.4 & 3.9 & 1.4 \\
\hline 3 & BERA & -0.1 & 1.7 & -4.6 & 1.7 \\
\hline 4 & BISK & 3.4 & 2.6 & 0.3 & 1.5 \\
\hline 5 & BUTE & 3.3 & 1.6 & 0.7 & 1.8 \\
\hline 6 & CAKO & 4.1 & 1.5 & 1.1 & 4.1 \\
\hline 7 & DUTH & -1.3 & 2.9 & 2.8 & 1.9 \\
\hline 8 & ISTA & 0.2 & 2.0 & 1.9 & 1.6 \\
\hline 9 & KATO & -0.1 & 1.8 & -0.6 & 1.3 \\
\hline 10 & LEHL & -0.4 & 2.2 & 9.0 & 2.3 \\
\hline 11 & NPAZ & 1.8 & 1.9 & 1.8 & 1.5 \\
\hline 12 & PASC & 3.9 & 1.3 & 4.2 & 1.6 \\
\hline 13 & POZE & 4.7 & 1.9 & 1.8 & 1.5 \\
\hline 14 & SFGH & 4.6 & 1.7 & 5.8 & 2.1 \\
\hline 15 & SKYR & -22.0 & 1.6 & -10.4 & 1.6 \\
\hline 16 & SRJV & 4.1 & 2.5 & 1.1 & 2.4 \\
\hline 17 & TRO3 & -2.4 & 2.8 & -3.6 & 2.0 \\
\hline 18 & VASL & 4.2 & 1.7 & 4.8 & 1.4 \\
\hline 19 & VATR & 1.9 & 2.0 & 2.5 & 1.8 \\
\hline 20 & VSBO & 0.6 & 1.4 & -4.9 & 1.6 \\
\hline
\end{tabular}

Since the coordinates of the daily solutions and the calculated velocities are determined in the coordinate system IGS-2014, there is a need to change the coordinate system to a regional one, hence this is the way to better visualize the regional kinematic processes. For this purpose, based on the results of the annual velocities of all GNSS stations, the average velocities for the whole network $\mathrm{V}_{\mathrm{N} \text {.avg }}=+11.7$ $\mathrm{mm} /$ year and $\mathrm{V}_{\mathrm{E} \text {. avg }}=+21.3 \mathrm{~mm} /$ year are determined. The annual regional velocities can be calculated as $\mathrm{V}_{\mathrm{B}}=\mathrm{V}_{\mathrm{N}}-\mathrm{V}_{\mathrm{N} \text {.avg }}$ and $\mathrm{V}_{\mathrm{L}}=\mathrm{V}_{\mathrm{E}}-\mathrm{V}_{\mathrm{E} \text {.avg. }}$

The part of the average regional horizontal velocities of GNSS stations in 2019 is presented in Table 1.

\section{Seismicity data}

In the research, the spatial data from EuropeanMediterranean Seismological Centre [EMSC] are used. 10 annual special seismicity catalogs from 2010 to 2019 are formed. The main parameters of the catalog are the coordinates of the earthquake, the depth of the hypocenter in kilometers and the local magnitude $\left(\mathrm{M}_{\mathrm{L}}\right)$ on the Richter magnitude scale. The minimum magnitude of the earthquakes is $\mathrm{M}_{\mathrm{L}}=1.5$. The deepest recorded earthquakes are at a depth $600 \mathrm{~km}$.

It is well-known that the regional seismic activity of a territory (the number of earthquakes and magnitude) in different years may decrease or increase, due to different planetary processes [Toksöz, et al., 1979, Vikulin et al., 2011]. Fig. 3 shows the annual numbers of earthquakes used in the study in 2010-2019. Fig. 4 illustrates the geographical position of earthquake epicenters in 2015 and 2019.

The highest annual seismic activity in the region was recorded in 2017 (6219 earthquakes), and high in 2013-2015 (over 5000 earthquakes). In 2018 and 2019, the number of earthquakes in the region decreased by half. The highest density of earthquake epicenters was concentrated in the southern part of the region.

During the last decade, the seismic event with the largest magnitude $\left(\mathrm{M}_{\mathrm{L}}=6.9\right)$ occurred in May 2014: hypocenter at a depth of $29 \mathrm{~km}$, epicenter coordinates are $\mathrm{B}=40.29^{\circ} \mathrm{L}=25.40^{\circ}$.

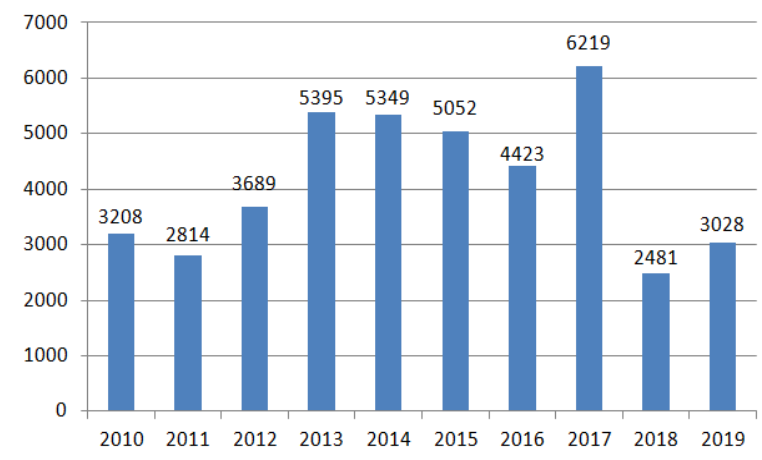

Fig. 3. The annual number of earthquakes used in the study during 2010-2019

\section{Methods}

In order to study in detail the deformations of the Earth's crust and seismicity, the Carpathian-Balkan region is divided into a continuous network of 
triangles with GNSS stations at the apexes. This division is based on the Delaunay triangulation principle and is used for each year of observations because of the number of GNSS stations annual changes.

Fig. 4 presents the Delaunay triangulation networks formed by the operating permanent GNSS stations in 2015 and 2019.

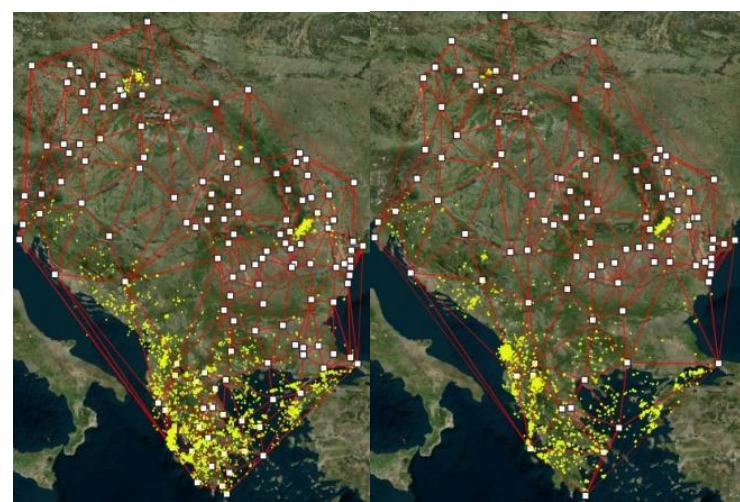

$\square$ - permanent GNSS station $\bigcirc$ - earthquake epicenter

Fig. 4. Networks of Delaunay triangulation formed by the permanent GNSS stations and earthquake epicenters in 2015 and 2019

According to the methods of [Tretyak \& Vovk 2014, Tretyak, et al. 2015], it is possible to calculate the horizontal deformations for each triangle based on the annual regional velocities of GNSS stations. The values of horizontal deformations are as follows: general shift $\gamma$ and its azimuth $\mathrm{A} \gamma$, dilatation $\Delta$, maximum compression $E_{1}$ or tension $E_{2}$ and $\Theta-$ azimuth of the main semi-axis of deformation.

As an example, Table 2 shows the part of generalized horizontal deformations for the Delaynay triangles in 2019. It is based on the part of the data given in Table 1

The fields of the annual distribution of dilatation and regional velocities of GNSS stations in the Carpathian-Balkan region during 2010-2019 are presented in Fig. 5. In general, during 2010-2019 the annual dilatations of the territory are quite similar as most permanent GNSS stations have a relatively stable annual trend. In general the maximum changes in the rate of dilatation are less than $50 \cdot 10^{-8} 1 /$ year. The southern part of the Balkan Peninsula in the regional coordinate system moves to the south-west. There is the compression in that zone up to $-40 \cdot 10^{-8}$ in 2010-2013 but later after the expansion in 2015 the trend of compression disappears. In the next 20162019 there is a slight expansion in the zone. In general, the largest expansions are in 2014, 2015 and contractions in 2010-2013.

In order to determine the generalized parameter of seismic events that occurred during a certain year in the area of a triangle, we use a generalized earthquake scattering ellipse [Tretyak, et al., 2008] with parameters of major semi-axis $a$, minor half-axis $b$ and azimuth of major semi-axis $\theta$.

Fig. 6 shows the theoretical location and azimuth of generalized earthquake scattering ellipse in the triangle with some earthquakes of varying magnitude $Z_{1} \ldots . . Z_{n}$.

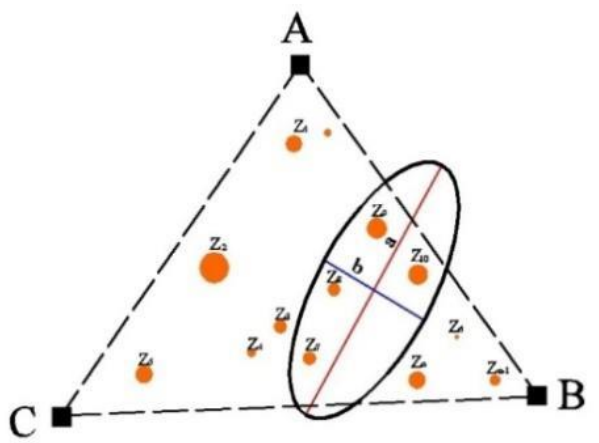

Fig. 6. Triangle formed by GNSS stations, located on the territories where earthquakes of varying magnitude $Z_{1} \ldots . Z_{n}$ had occurred [Tretyak \& Romaniuk, 2018]

The major and minor semi-axes of the scattering ellipse of the earthquake epicenters ( $a$ and $b$ ) can be calculated as values of correlation matrix $Q$ :

$$
Q=\left|\begin{array}{ll}
a_{11} & a_{12} \\
a_{21} & a_{22}
\end{array}\right| Q=\left|\begin{array}{ll}
a_{11} & a_{12} \\
a_{21} & a_{22}
\end{array}\right|
$$

where:

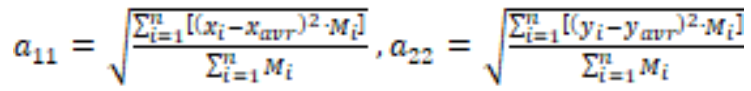

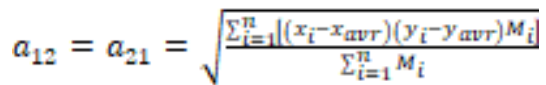

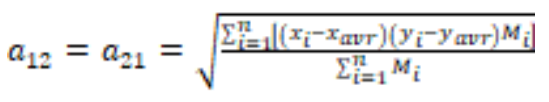

where:

$$
\begin{aligned}
& x_{\text {GUY }}=\frac{\sum_{i=1}^{M} x_{1} M_{i}}{\sum_{i=1}^{M L} M_{i}} x_{\text {GUY }}=\frac{\sum_{i=1}^{M} x_{i} M_{i}}{\sum_{i=1}^{M} M_{i}} \\
& y_{a v y}=\frac{\sum_{i=1}^{n} y_{i} M_{i}}{\sum_{i=1}^{M} M_{i}} Y_{a W y}=\frac{\sum_{i=1}^{M} y_{i} M_{i}}{\sum_{i=1}^{M} M_{i}}
\end{aligned}
$$

$x_{i}, y_{i}$ - the coordinates of earthquake epicenters located within the selected triangle; $n$ - the number of earthquakes recorded for a certain period of time; $M$ - the magnitude of the earthquake.

Azimuth of semi-major axis defined by the following equation:

$$
\begin{gathered}
\theta= \begin{cases}\frac{1}{2} \operatorname{arctg}\left(\frac{2 a_{12}}{a_{11}^{2}-a_{22}^{2}}\right) & , a_{11}>a_{22} \\
\frac{1}{2} \operatorname{arctg}\left(\frac{2 a_{12}}{a_{11}^{2}-a_{22}^{2}}\right)+90^{\circ}, & a_{11}<a_{22}\end{cases} \\
\theta= \begin{cases}\frac{1}{2} \operatorname{arctg}\left(\frac{2 a_{12}}{a_{11}^{2}-a_{22}^{2}}\right) & , a_{11}>a_{22} \\
\frac{1}{2} \operatorname{arctg}\left(\frac{2 a_{12}}{a_{11}^{2}-a_{22}^{2}}\right)+90^{\circ}, & a_{11}<a_{22}\end{cases}
\end{gathered}
$$



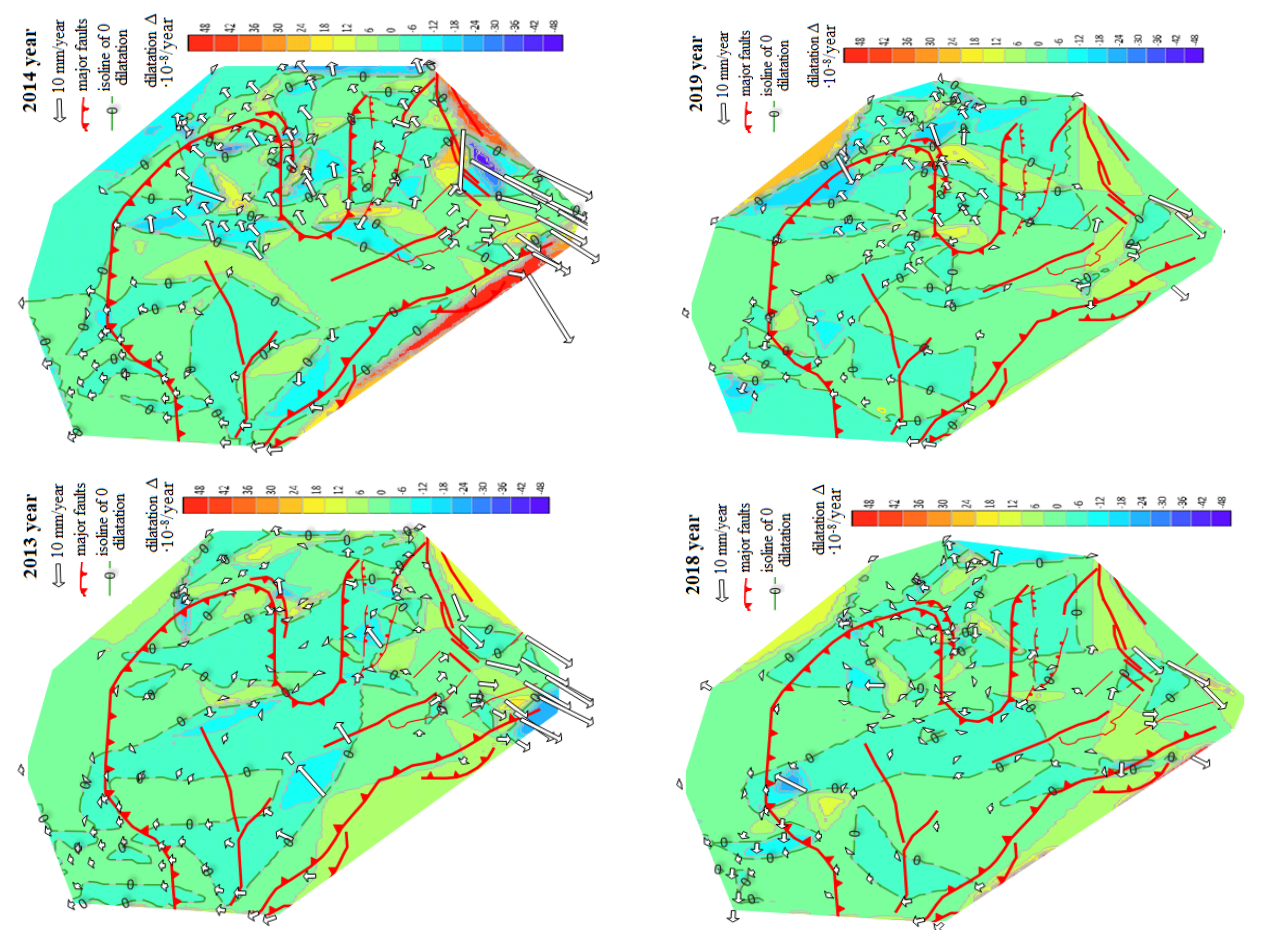

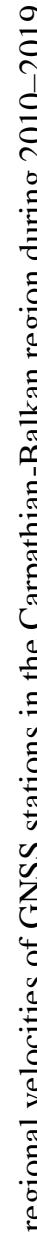
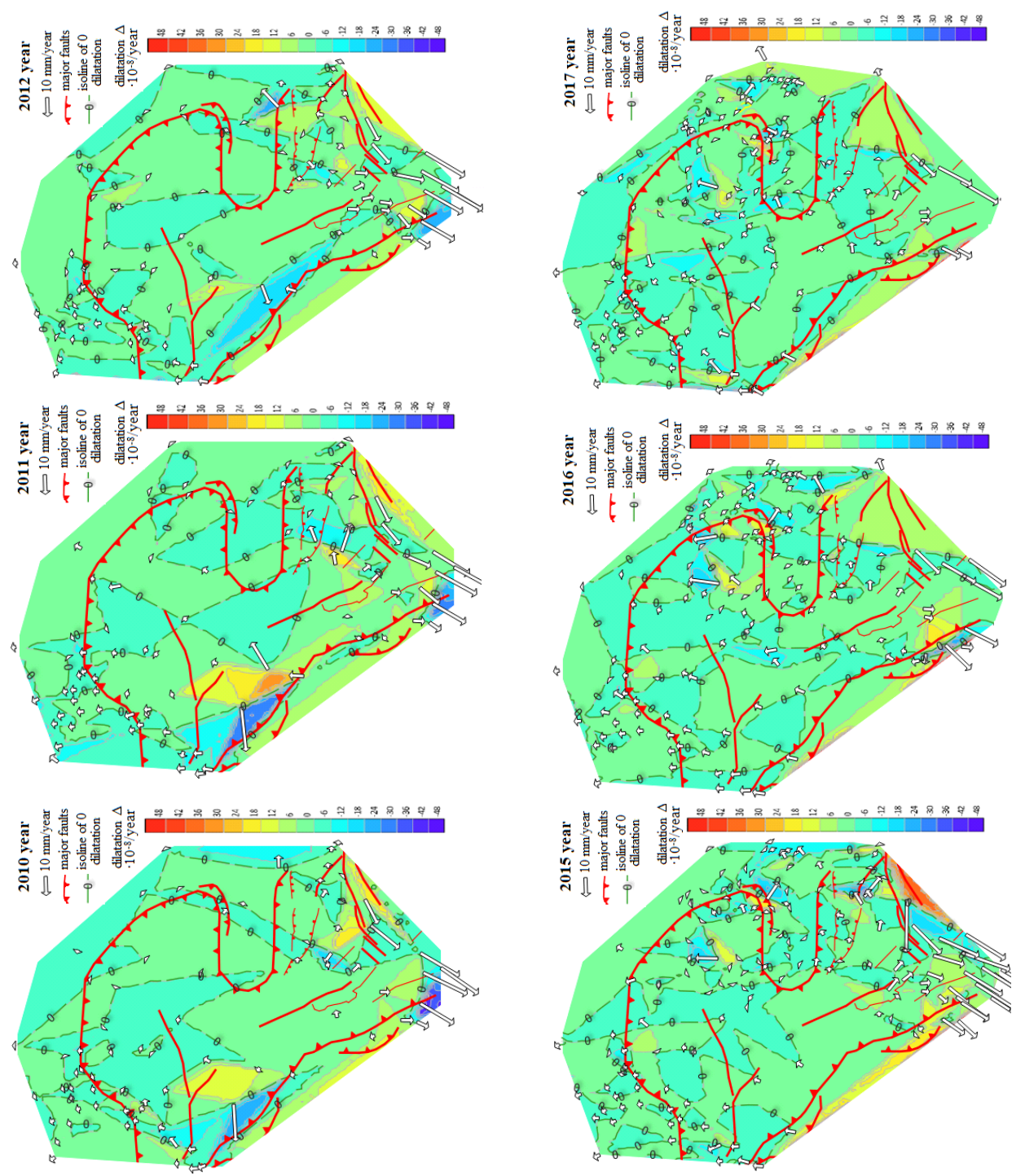

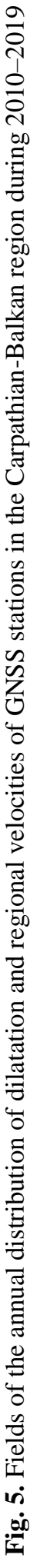


The bigger semi-axes of the scattering ellipse of the earthquake epicenters are, the larger the area the epicenters of the earthquakes cover, and the more uniform the distribution of earthquakes within the triangle is.

Table 3 demonstrates the part of generalized seismic parameters in 2019.

So, the parameters of horizontal deformations are annually determined (see Table 2). And besides, generalized seismicity as parameters of the earthquake scattering ellipse (see Table 3) for each triangle is calculated.

Depending on the spatial location of tectonic blocks and its movements the Earth's surface can compress or expand. That is why the absolute value of dilatation may be used to generalize the movements.

In order to establish correlations between horizontal deformations of the Earth's crust and seismicity, we conducted a comparative analysis of the major semi-axes of the scattering ellipse of the earthquake epicenters and the absolute value of dilatation for each Delaunay triangle in a year.

To do this, two triangles are determined from the formed array of annual dilatation data and the major semi-axes of the scattering ellipse by the method of search of all combinations. This corresponds to the maximum correlation between the parameters $|\Delta|$ a nd $a$.
For 2019, there are two triangles number 155 (VASL, $P A S C, B A C A)$ and 81 (SFGH, VATR, ABIU), with the correlation coefficient $K$ equal to 1 (Table 4$)$. Then the number of the selected triangles by the criterion of the maximum correlation coefficient between the parameters $a$ and $|\Delta|$ is iteratively increased.

Fig. 7 presents $a$ graph of changes of semi-major axis of ellipse of scattering earthquake epicenters and absolute dilatation with increasing number of correlated triangles in 2019. It is seen that the curves of changes of parameters a and $|\Delta|$ are much likely synchronous for the first 23 triangles. But the subsequent increase of new triangles leads to loss of synchronicity of change of these curves (see I and II zones in Fig. 7).

The curve of reduction correlation coefficient in the set of triangles between $a$ and $|\Delta|$ is shown in Fig. 8. Conventionally this curve can be also divided into two parts, I and II. The first part of the curve is characterized by a slow decrease in the correlation coefficient between the parameters $a$ and $|\Delta|$ and the second part of the curve, which is characterized by a rapid decrease in the correlation coefficient.

In this manner, according to the results of 2019, the triangles of the first group (I) have a high correlation between the parameters $a$ and $|\Delta|$. The group of triangles that have a high correlation between $a$ and $|\Delta|$ is limited to 23 triangles with a correlation coefficient of 0.915 (see table 4).

Table 2

Part of generalized horizontal deformations for the Delaunay triangles in 2019

\begin{tabular}{|c|c|c|c|c|c|c|c|c|c|}
\hline \multirow{2}{*}{$\begin{array}{c}\text { The } \\
\text { number } \\
\text { of } \\
\text { triangle }\end{array}$} & \multicolumn{3}{|c|}{ The names apex of triangle } & \multirow{2}{*}{$\begin{array}{c}\Delta \\
10^{-8}, \\
1 / \text { year }\end{array}$} & \multirow{2}{*}{$\begin{array}{c}\gamma \\
10^{-8}, \\
1 / \text { year }\end{array}$} & \multirow{2}{*}{$\underset{\circ}{\mathrm{A}_{\gamma},}$} & \multirow{2}{*}{$\begin{array}{l}\mathrm{E}_{1} \\
10^{-8}, \\
1 / \text { year }\end{array}$} & \multirow{2}{*}{$\begin{array}{c}\mathrm{E}_{2} \\
10^{-8}, \\
1 / \text { year }\end{array}$} & \multirow{2}{*}{$\underset{\circ}{\Theta}$} \\
\hline & I & II & III & & & & & & \\
\hline 155 & VASL & PASC & BACA & 2.62 & 0.16 & 86 & 24.10 & 2.04 & 43 \\
\hline 81 & SFGH & VATR & $\mathrm{ABIU}$ & -1.19 & -1.93 & 219 & 6.55 & -18.40 & 20 \\
\hline 177 & SKYR & ISTA & DUTH & 8.09 & 8.46 & 35 & 91.80 & -10.90 & 17 \\
\hline 109 & BUTE & CAKO & POZE & -0.45 & -0.69 & 219 & 2.19 & -6.66 & 19 \\
\hline 167 & DUTH & LEHL & TRO3 & 9.25 & -10.10 & 185 & 96.80 & -4.28 & 3 \\
\hline 103 & BISK & VSBO & KATO & 1.89 & 3.35 & 65 & 49.60 & -30.70 & 33 \\
\hline 112 & SRJV & BERA & NPAZ & 2.25 & -0.53 & 113 & 17.90 & 4.60 & 147 \\
\hline
\end{tabular}

Table 3

Part of generalized seismic parameters in 2019

\begin{tabular}{|c|c|c|c|c|c|c|c|}
\hline $\begin{array}{c}\text { The } \\
\text { number } \\
\text { of } \\
\text { triangle }\end{array}$ & \multicolumn{2}{|c|}{ The names apex of triangle } & \multirow{2}{*}{$\begin{array}{c}\text { Semi- } \\
\text { minor } \\
\text { axes } \\
b, \mathrm{~km}\end{array}$} & $\begin{array}{c}\text { Semi-major } \\
\text { axes } \\
a, \mathrm{~km}\end{array}$ & $\begin{array}{c}\text { Azimuth of } \\
\text { semi-major } \\
\text { axis } \\
\theta,^{\circ}\end{array}$ & $\begin{array}{c}\text { The number of } \\
\text { earthquakes }\end{array}$ \\
\hline 155 & VASL & PASC & BACA & 0.001 & 0.336 & 20 & 2 \\
\hline 81 & SFGH & VATR & ABIU & 0.001 & 0.157 & 143 & 2 \\
\hline 177 & SKYR & ISTA & DUTH & 0.163 & 1.077 & 160 & 342 \\
\hline 109 & BUTE & CAKO & POZE & 0.001 & 0.027 & 39 & 2 \\
\hline 167 & DUTH & LEHL & TRO3 & 0.001 & 1.292 & 36 & 2 \\
\hline 103 & BISK & VSBO & KATO & 0.023 & 0.196 & 162 & 12 \\
\hline 112 & SRJV & BERA & NPAZ & 0.178 & 0.344 & 167 & 279 \\
\hline
\end{tabular}


The annual number of the selected triangles with a high correlation between the parameters $a$ and $|\Delta|$ is given in table 5. Fig. 9 shows mapping territories of triangles covered by the high degree of correlative connection between $a$ and $|\Delta|$ in 2010-2019.

Table 4

Part of triangles by the maximum of correlation coefficient $K$ between the parameters $a$ and $|\Delta|$ according to seismic activity and GNSS measurements in 2019

\begin{tabular}{|c|c|c|c|c|c|c|c|}
\hline \multirow{2}{*}{ № } & \multirow{2}{*}{$\begin{array}{l}\text { The number } \\
\text { of triangle }\end{array}$} & \multicolumn{3}{|c|}{ The names apex of triangle } & \multirow{2}{*}{$\begin{array}{c}\text { Semi-major } \\
\text { axes } \\
a, \mathrm{~km}\end{array}$} & \multirow{2}{*}{$\begin{array}{c}\text { Absolute } \\
\text { dilatation } \\
|\Delta| 10^{-8}, 1 / \text { year }\end{array}$} & \multirow{2}{*}{$\begin{array}{c}\text { Correlation } \\
\text { coefficient } \\
K \\
\end{array}$} \\
\hline & & I & II & III & & & \\
\hline & 155 & VASL & PASC & BACA & 0.336 & 2.62 & 1 \\
\hline 2 & 81 & SFGH & VATR & ABIU & 0.157 & 1.19 & 1 \\
\hline 3 & 177 & SKYR & ISTA & DUTH & 1.077 & 8.09 & 1 \\
\hline 4 & 109 & BUTE & CAKO & POZE & 0.027 & 0.45 & 1 \\
\hline 5 & 167 & DUTH & LEHL & TRO3 & 1.292 & 9.25 & 0.999 \\
\hline 6 & 103 & BISK & VSBO & KATO & 0.196 & 1.89 & 0.999 \\
\hline 7 & 112 & SRJV & BERA & NPAZ & 0.344 & 2.25 & 0.998 \\
\hline 8 & 32 & SRJV & SABA & POZE & 0.071 & 1.27 & 0.998 \\
\hline 9 & 36 & DMDM & KNJA & DRTS & 0.227 & 1.41 & 0.997 \\
\hline 10 & 34 & DMDM & DRTS & BUZE & 0.146 & 1.70 & 0.996 \\
\hline 11 & 13 & GANP & PENC & OROS & 0.122 & 1.64 & 0.994 \\
\hline 12 & 147 & DUTH & AUT1 & SKYR & 0.488 & 3.20 & 0.992 \\
\hline 13 & 79 & TGTS & BUZA & ADJU & 0.059 & 1.59 & 0.988 \\
\hline 14 & 148 & SOFI & DUTH & TRO3 & 0.488 & 4.85 & 0.985 \\
\hline 15 & 141 & GRAZ & TRIE & GSR1 & 0.403 & 1.69 & 0.981 \\
\hline 16 & 116 & NOA1 & VLSM & NEAB & 0.793 & 4.71 & 0.976 \\
\hline 17 & 108 & GRAZ & GSR1 & CAKO & 0.251 & 0.54 & 0.970 \\
\hline 18 & 48 & ORID & AUT1 & SOFI & 0.548 & 2.83 & 0.958 \\
\hline 19 & 115 & KLOK & NOA1 & LARM & 0.297 & 0.45 & 0.950 \\
\hline 20 & 144 & SRJV & POZE & ZADA & 0.205 & 0.09 & 0.943 \\
\hline 21 & 50 & LARM & NOA1 & SKYR & 0.370 & 5.18 & 0.931 \\
\hline 22 & 47 & SOFI & DUTH & AUT1 & 0.470 & 1.86 & 0.925 \\
\hline 23 & 25 & CAKO & POZE & ZADA & 0.372 & 0.37 & 0.915 \\
\hline 24 & 138 & KATO & WROC & BISK & 0.014 & 2.00 & 0.894 \\
\hline 25 & 35 & SABA & SRJV & NPAZ & 0.398 & 1.27 & 0.873 \\
\hline 26 & 142 & ZADA & GSR1 & CAKO & 0.481 & 0.81 & 0.858 \\
\hline 27 & 41 & NPAZ & DMDM & KNJA & 0.391 & 0.68 & 0.845 \\
\hline 28 & 146 & MAL3 & KLOK & VLSM & 0.580 & 7.63 & 0.832 \\
\hline 29 & 164 & ZADA & BERA & SRJV & 0.637 & 1.82 & 0.814 \\
\hline 30 & 38 & NPAZ & KNJA & ORID & 0.695 & 1.22 & 0.792 \\
\hline
\end{tabular}

Table 5

Annual values of triangles with the high correlation coefficient between $a$ and $|\Delta|$

\begin{tabular}{|c|c|c|}
\hline Year & Correlation coefficient & The number of triangles \\
\hline 2010 & 0.88 & 22 \\
\hline 2011 & 0.89 & 31 \\
\hline 2012 & 0.84 & 30 \\
\hline 2013 & 0.88 & 41 \\
\hline 2014 & 0.84 & 31 \\
\hline 2015 & 0.87 & 45 \\
\hline 2016 & 0.87 & 35 \\
\hline 2017 & 0.92 & 30 \\
\hline 2018 & 0.87 & 32 \\
\hline 2019 & 0.91 & 23 \\
\hline
\end{tabular}




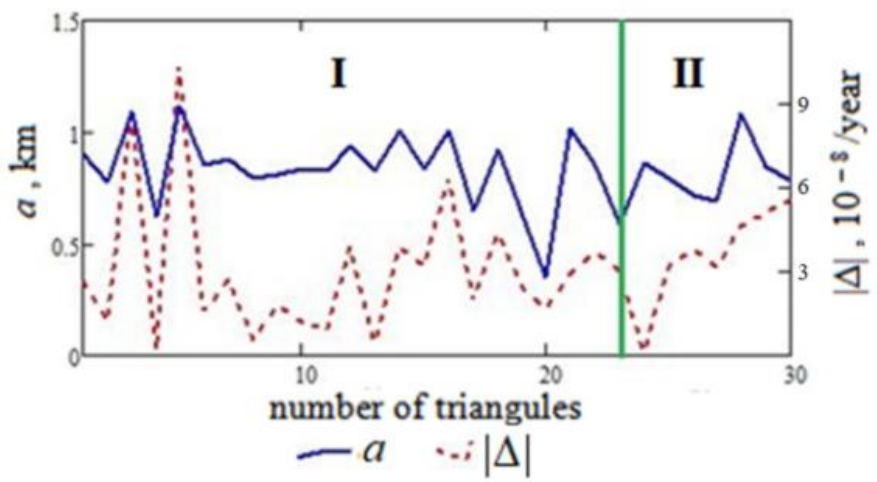

Fig. 7. Changing of semi-major axis of ellipse of scattering earthquake epicenters and absolute dilatation in 2019

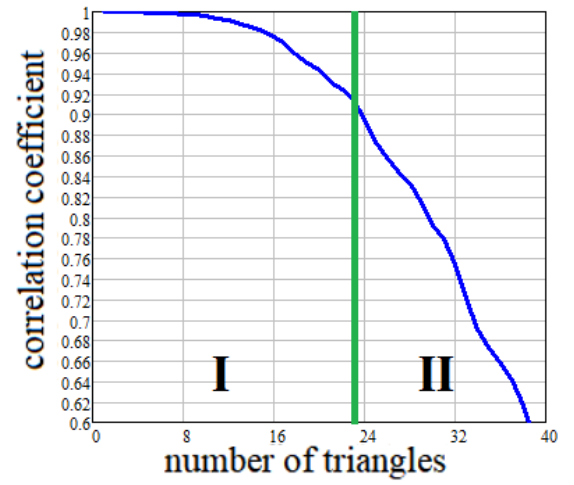

Fig. 8. Curve of reduction correlation coefficient in the set of triangles between $a$ and $|\Delta|$ in 2019
The method proposed in [Tretyak \& Romaniuk, 2018] is used in order to determine territories covered by high degree of correlative connection between the major semi-axis of the earthquake scattering ellipse $a$ and absolute dilatation $|\Delta|$. The entire territory of the Carpathian-Balkan region is divided into a grid of points in the apex of squares with a side of $10 \mathrm{~km}$. The triangle is determined for each point in which it is located. If the defined triangle is selected in a number of triangles with a high degree of correlation between the parameters $a$ and $|\Delta|$, the point is assigned a value of 1 , otherwise 0 .

After every point for all years was checked, the sum of the assigned values for all years of observations corresponds to the number of years in which the given point was in a triangle with a high degree of correlation between the parameters $a$ and $|\Delta|$ Thus, if every year from 2010 to 2019 the point was within the triangles with high correlation, the number of points would be 10 , if none of the year it would be 0 . After the appropriate calculations, it was found out that there are points with a maximum value of 8 for the studied region.

Fig. 10 illustrates the areas in which the correlation between the parameters $a$ and $|\Delta|$ is more than 5 years in 2010-2019 (yellow zones). It should be noted that all selected areas with a high degree of correlations between seismicity and horizontal deformations border on the lines of active faults. The largest area with a high correlation covers the Rhodopes and subduction zone between Nubia and Europa tectonic units. The area of high correlation also coincides with Vrancea. According to research [Pamić, 2002], the Sava Suture Zone (see green line in Fig. 10) is the suture of the junction of the Rhodopes, the Hellenides and the Adria microplate that in general can be identified as subduction zone of African and Eurasian tectonic plates.
Fig. 11 presents a cross section of tectonic structures of Dinarides-Hellenides, the trace of which is shown in Fig. 10. The profile also shows the locations of earthquake hypocenters in 2010-2019 and the zone of the high correlation between the parameters $a$ and $|\Delta|$. The Rhodopes expand in the direction perpendicular to the fault axis, and the Hellenids, on the other hand, undergo compression [Nagel et al., 2011].

Accordingly, it can be assumed that the correlation between the horizontal deformations determined by GNSS data and generalized seismicity is detected only in the subduction zones, where there is an intense seismic activity as well as deformations of the Earth's crust. This is confirmed by the detected correlation zones (see Fig. 10) which are located on one side of the active faults.

It should be noted that the zones of high correlations between generalized seismicity and vertical movements of the Earth's crust [Tretyak \& Romaniuk, 2018] are much larger than the zones of correlations with horizontal deformations. This may indicate that seismic energy primarily causes the vertical movements of the Earth's crust. So, horizontal deformations may be derived from vertical ones. In the subduction zones the appearance of horizontal tensions is caused by the collision of two plates which causes seismic events. Then, released seismic energy may in turn lead to vertical and horizontal deformations and this process is cyclical.

In the future, it is necessary to improve the research methodology by adding new generalized seismicity criteria related to magnitude, energy and depth of earthquake hypocenters. Then the improved methodology should be tested on the results of measurements of other seismically active regions taking into account different deformation parameters. 

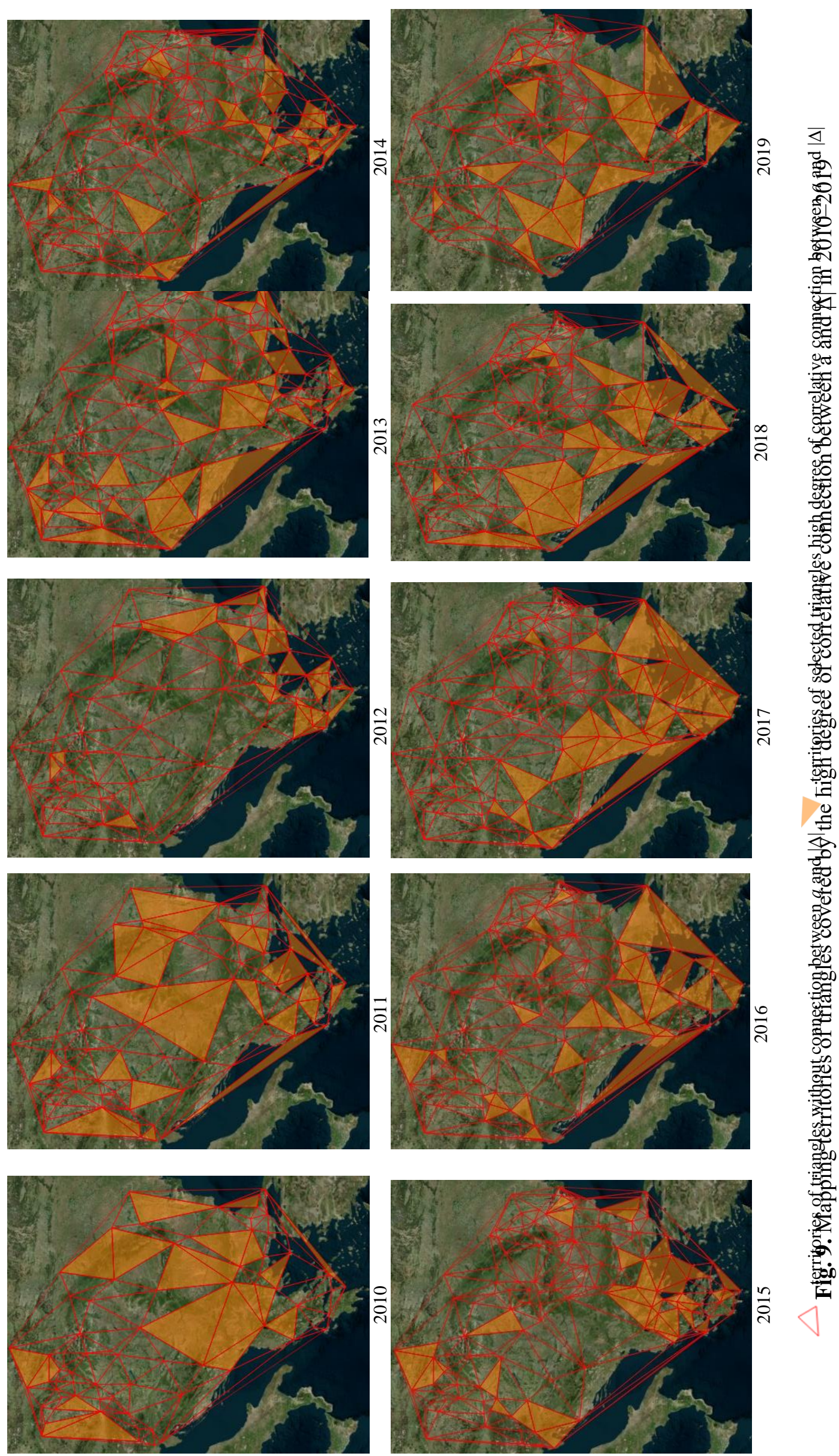


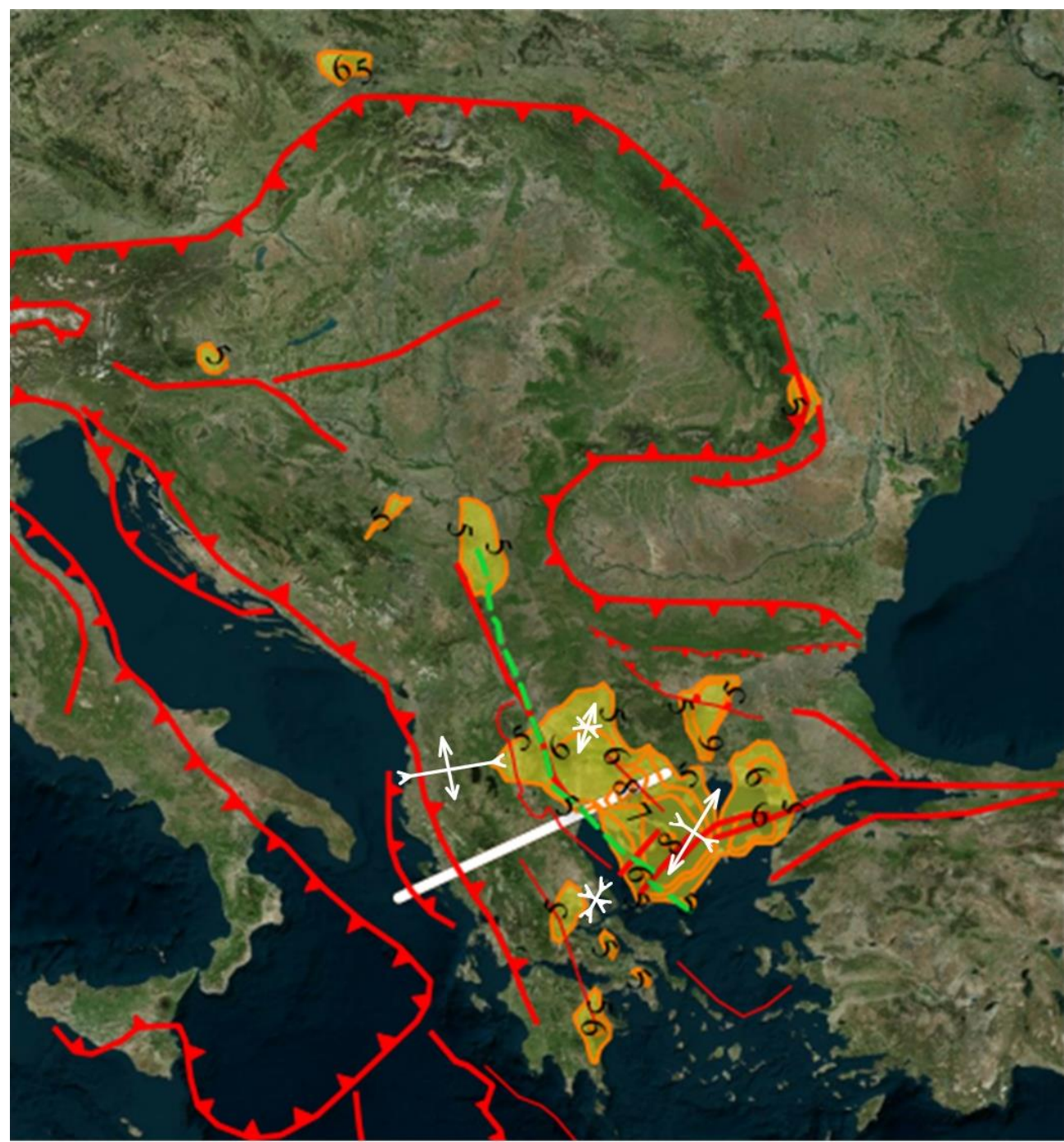

$\checkmark$ - territories with the annual high degree of correlative connection between $a$ and $|\Delta|$; $\quad$-main faults; - Sava Suture Zone;

Fig. 10. Mapping territories covered by annual high degree of correlative connection between $a$ and $|\Delta|$ in 2010-2019 (added profile from [Handy et. al, 2019])

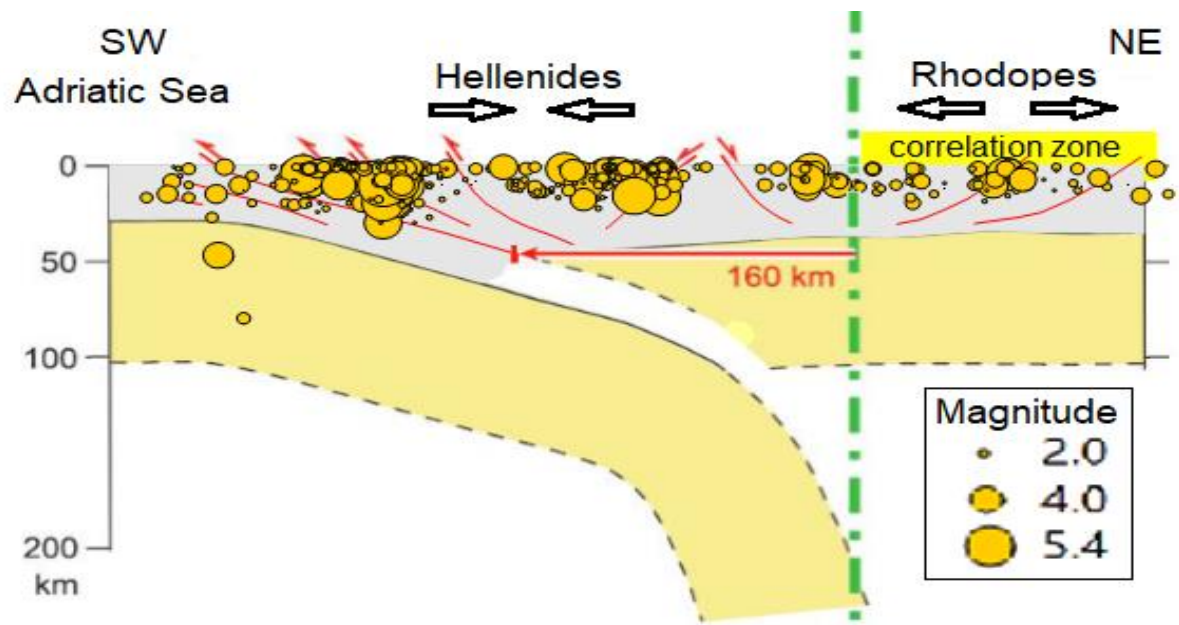

Fig. 11. Cross section of tectonic structures of Dinarides-Hellenides with earthquake hypocenters (modified from [Handy, et al., 2019; Nagel,et al., 2011]) 


\section{Results and conclusions}

1. The paper presents the method for identifying interrelations between the values of the generalized criteria of horizontal deformations of the Earth's crust and generalized seismicity.

2. The studies of the annual distribution of dilatation according to GNSS data as well as the development of special maps for the CarpathianBalkan region in 2010-2019 are done. According to the seismic data, the annual parameters of generalized seismicity are determined for Delaunay triangles with GNSS stations in apexes.

3. Based on the analysis of the obtained results, the search for correlations between the absolute values of dilatation and the major semi-axes of the scattering ellipse of the earthquake epicenters is carried out. The annual correlative zones and total correlative territory with a high degree of annual correlation (> 0.84) between these parameters are selected.

4. All the selected territories with a high degree of correlations between seismicity and horizontal deformations border on the lines of active faults which are the subduction zones. The largest area with a high correlation covers the Rhodopes, where there is the collision between Nubia and Eurasian plates. The area of high correlation also coincides with the Vrancea zone.

5. According to the research, it can be assumed that the correlation between horizontal deformations determined according to GNSS data and generalized seismicity appears only in subduction zones, characterized by an intense seismic activity as well as regular deformations of the Earth's crust. This is confirmed by the location of correlation zones on one side of the active faults.

6. The spatial zones of high correlations between generalized seismicity and vertical movements of the Earth's crust [Tretyak \& Romaniuk, 2018] are much larger than the zones of correlations with horizontal deformations. This may indicate that seismic energy primarily causes the vertical movements of the Earth's crust. So horizontal deformations may be derived from vertical ones. In the subduction zones the appearance of horizontal tensions is caused by the collision of two plates, which cause seismic events. Then, released seismic energy may in turn lead to vertical and horizontal deformations and this process is cyclical.

\section{References}

Altiner, Y., Marjanović, M., Medved, M., \& Rasić, L. (2006). Active deformation of the Northern Adriatic region: Results from the CRODYN geodynamical experiment. In The Adria Microplate: GPS Geodesy, Tectonics and Hazards (pp. 257-267). Springer, Dordrecht.

Benford, B., DeMets, C., \& Calais, E. (2012). GPS estimates of microplate motions, northern
Caribbean: Evidence for a Hispaniola microplate and implications for earthquake hazard. Geophysical Journal International, 191(2), 481-490.

Blewitt, G., W. C. Hammond, and C. Kreemer (2018), Harnessing the GPS data explosion for interdisciplinary science, Eos, 99, https://doi.org/10.1029/2018EO104623

Bocchini, G. M., Brüstle, A., Becker, D., Meier, T., van Keken, P. E., Ruscic, M., ... \& Friederich, W. (2018). Tearing, segmentation, and backstepping of subduction in the Aegean: New insights from seismicity. Tectonophysics, 734, 96-118.

Burchfiel, B. C., King, R. W., Todosov, A., Kotzev, V., Durmurdzanov, N., Serafimovski, T., \& Nurce, B. (2006). GPS results for Macedonia and its importance for the tectonics of the Southern Balkan extensional regime. Tectonophysics, 413(3-4), 239-248.

Caporali, A., Aichhorn, C., Barlik, M., Becker, M., Fejes, I., Gerhatova, L., ... \& Medak, D. (2009). Surface kinematics in the Alpine-CarpathianDinaric and Balkan region inferred from a new multi-network GPS combination solution. Tectonophysics, 474(1-2), 295-321.

Cenni, N., Viti, M., \& Mantovani, E. (2015). Space geodetic data (GPS) and earthquake forecasting: examples from the Italian geodetic network. Bollettino di Geofisica Teorica ed Applicata, 56(2).

Centre Sismologique Euro-Mediterraneen. (n.d.) Retrived from: https://www.emsc-csem.org

Chousianitis, K., Ganas, A., \& Gianniou, M. (2013). Kinematic interpretation of present-day crustal deformation in central Greece from continuous GPS measurements. Journal of Geodynamics, 71, $1-13$.

Faccenna, C., Becker, T. W., Auer, L., Billi, A., Boschi, L., Brun, J. P., ... \& Piromallo, C. (2014). Mantle dynamics in the Mediterranean. Reviews of Geophysics, 52(3), 283-332.

Gintov, O., Murovskaya, A., Egorova, T., Wolfman, Yu., Tsvetkova, T., Vugaenko, I, .. \& Amashukeli, T A. (2015). Deep seismogenic zone Vrancea as an indicator of geodynamic process. Geophisicheskiy zhurnal, 22-49. (in Russian).

Grenerczy, G., Sella, G., Stein, S., \& Kenyeres, A. (2005). Tectonic implications of the GPS velocity field in the northern Adriatic region. Geophysical Research Letters, 32(16).

Gulal, E., Tiryakioglu, I., Kalyoncuoglu, U. Y., Erdogan, S., Dolmaz, M. N., \& Elitok, O. (2016). The determination of relations between statistical seismicity data and geodetic strain analysis, and the analysis of seismic hazard in southwest Anatolia. Geomatics, Natural Hazards and Risk, 7(1), 138-155.

Halpaap, F., Rondenay, S., \& Ottemöller, L. (2018). Seismicity, deformation, and metamorphism in the Western Hellenic subduction zone: New constraints from tomography. Journal of Geophysical Research: Solid Earth, 123(4), 3000-3026. 
Handy, M. R., Giese, J., Schmid, S. M., Pleuger, J., Spakman, W., Onuzi, K., \& Ustaszewski, K. (2019). Coupled Crust-Mantle Response to Slab Tearing, Bending, and Rollback Along the Dinaride-Hellenide Orogen. Tectonics, 38(8), 2803-2828.

Hollenstein, C., Müller, M. D., Geiger, A., \& Kahle, H. G. (2008). Crustal motion and deformation in Greece from a decade of GPS measurements, 1993-2003. Tectonophysics, 449(1-4), 17-40.

Ioane, D., \& Stanciu, I. M. (2018). Extensional tectonics in Vrancea zone (Romania) interpreted on recent seismicity, geophysical and GPS data. Proc. SGEM 2018, 18, 939-946.

Ismail-Zadeh, A., Matenco, L., Radulian, M., Cloetingh, S., \& Panza, G. (2012). Geodynamics and intermediate-depth seismicity in Vrancea (the south-eastern Carpathians): current state-of-the art. Tectonophysics, 530, 50-79.

Jouanne, F., Mugnier, J. L., Koci, R., Bushati, S., Matev, K., Kuka, N., ... \& Duni, L. (2012). GPS constraints on current tectonics of Albania. Tectonophysics, 554, 50-62.

Kao, H., Hyndman, R., Jiang, Y., Visser, R., Smith, B., Babaie Mahani, A., ... \& He, J. (2018). Induced seismicity in western Canada linked to tectonic strain rate: Implications for regional seismic hazard. Geophysical Research Letters, 45(20), 11-104.

Kotzev, V., Nakov, R., Georgiev, T., Burchfiel, B. C., \& King, R. W. (2006). Crustal motion and strain accumulation in western Bulgaria. Tectonophysics, 413(3-4), 127-145.

Mazzotti, S., Leonard, L. J., Cassidy, J. F., Rogers, G. C., \& Halchuk, S. (2011). Seismic hazard in western Canada from GPS strain rates versus earthquake catalog. Journal of Geophysical Research: Solid Earth, 116(B12).

Meyer, M. B. (2011). GPS constrains on current tectonics of soutwest bulgaria, northern greece, and albania (Doctoral dissertation, University of Grenoble).

Nagel, T. J., Schmidt, S., Janák, M., Froitzheim, N., Jahn-Awe, S., \& Georgiev, N. (2011). The exposed base of a collapsing wedge: the Nestos shear zone (Rhodope Metamorphic Province, Greece). Tectonics, 30(4).

Pearce, F. D., Rondenay, S., Sachpazi, M., Charalampakis, M., \& Royden, L. H. (2012). Seismic investigation of the transition from continental to oceanic subduction along the western Hellenic Subduction Zone. Journal of Geophysical Research: Solid Earth, 117(B7).

Pena Castellnou, S. (2018). Present-day 3D GPS velocity field of the Iberian Peninsula and implications for seismic hazard.

Pospisil, L., Bartonek, D., Hefty, J., \& Machotka, R. (2019, January). Geodetic Signs of the Recent Kinematical and Geodynamical Deformation of the Carpathian Arc. In IOP Conference Series: Earth and Environmental Science (Vol. 221, No. 1, p. 012001). IOP Publishing.
Riguzzi, F., Crespi, M., Devoti, R., Doglioni, C., Pietrantonio, G., \& Pisani, A. R. (2012). Geodetic strain rate and earthquake size: New clues for seismic hazard studies. Physics of the Earth and Planetary Interiors, 206, 67-75.

Siejka, Z. (2010). Analysis of the series of time coordinates of the local KRUR reference station in Kraków. Infrastruktura i ekologia terenów wiejskich, 12, 107-114, (in Polish).

Toksöz, M. N., Shakal, A. F., \& Michael, A. J. (1979). Space-time migration of earthquakes along the North Anatolian fault zone and seismic gaps. Pure and Applied Geophysics, 117(6), 1258-1270.

Tretyak, K. and Romaniuk, V.: 2014, Investigation of the relationship between modern vertical displacements of the Earth's crust and seismic activity in Europe. Geodinamika, No. 1, 7-20, (in Ukrainian).

Tretyak, K. and Vovk, A.: 2014, Results of determination of horizontal deformation of the Earth's crust of Europe according to the data of GNSS observations and their relation with the tectonics structure. Geodinamika, 16, No. 1, 21-33, (in Ukrainian).

Tretyak, K. R., Maksimchuk, V. Y., Kutas, R. I., Rokityansky, I. I., Gnilko, A. N., Kendzera, A. V., \& Tereshin, A. V. (2015). Modern geodynamics and geophysical fields of the Carpathians and adjacent territories. Lviv: Publishing House of Lviv Polytechnic (in Ukrainian).

Tretyak, K., \& Romaniuk, V. (2018). The research on the interrelation between seismic activity and modern vertical movements of the european permanent GNSS-stations. Acta Geodynamics et Geomaterial, 15(2), 143-164.

Tretyak, K., Serant O. and Smirnova, O.: 2008, The connection between the horizontal deformations of the earth`s surface and the seismic activity of central Europe, Suchasni dosyagnennya geodezichnoi nauki ta virobnitstva, 15 (1) (in Ukrainian).

Ustaszewski, K., Herak, M., Tomljenović, B., Herak, D., \& Matej, S. (2014). Neotectonics of the DinaridesPannonian Basin transition and possible earthquake sources in the Banja Luka epicentral area. Journal of Geodynamics, 82, 52-68.

Van der Hoeven, A. G. A., Mocanu, V., Spakman, W., Nutto, M., Nuckelt, A., Matenco, L., ... \& Ambrosius, B. A. C. (2005). Observation of presentday tectonic motions in the Southeastern Carpathians: results of the ISES/CRC-461 GPS measurements. Earth and Planetary Science Letters, 239(3-4), 177-184.

Vikulin, A. V., Akmanova, D. R., Vikulina, S. A., \& Dolgaya, A. A. (2012). Migration of seismic and volcanic activity as display of wave geodynamic process. Geodynamics \& Tectonophysics, 3(1), 1-18.

Vrabec, M., Preseren, P. P., \& Stopar, B. O. J. A. N. (2006). GPS study (1996-2002) of active deformation along the Periadriatic fault system in northeastern Slovenia: tectonic model. Geologica Carpathica-Bratislava-, 57(1), 57. 


\section{К. Р. ТРЕТЯК, І. В. БРУСАК}

Кафедра вищої геодезії та астрономії, Національний університет “Львівська політехніка”, вул. С. Бандери, 12, Львів, 79013, Україна

\section{ДОСЛІДЖЕННЯ ВЗАСМОЗВ’ЯЗКУ СЕЙСМІЧНОСТІ ТА СУЧАСНИХ ГОРИЗОНТАЛЬНИХ ЗМІЩЕНЬ ЗА ДАНИМИ ПЕРМАНЕНТНИХ ГНСС-СТАНЦІЙ У КАРПАТО-БАЛКАНСЬКОМУ РЕГІОНІ}

Проблема прогнозу землетрусів та їх взаємозв'язку з горизонтальними деформаціями земної кори досі не вирішена. У цій роботі метою є пошук просторово-часових взаємозв'язків між величинами узагальнених критеріїв поля горизонтальних швидкостей земної кори та узагальненої сейсмічності. Як полігон досліджень обрано територію Карпато-Балканського регіону, в зв'язку з широкою диференціацією сейсмічної активності та добре дослідженою геологічною структурою регіону. Методика. За даними мереж ГНСС-станцій у період з 2010-2019 рр. проаналізовано горизонтальні деформації території Карпато-Балканського регіону та побудовано карти розподілу швидкостей дилатацій. За даними сейсмічних станцій визначено щорічні параметри узагальненої сейсмічності для окремих блоків, у вершинах яких знаходяться ГНСС-станції. На основі просторово-часового аналізу горизонтальних деформацій та узагальненої сейсмічності, проведено пошук кореляційних взаємозв'язків між абсолютним значеннями дилатації та узагальненими параметрами сейсмічності територій. У результаті виділено сталі зони, з високим ступенем кореляції між абсолютним значеннями дилатації та великою піввіссю еліпса розсіювання землетрусів. Найбільша за площею територія 3 високою кореляцією охоплює Родопский масив, зону занурення Африканської плити під Євразійську. Територія високої кореляції також співпадає з зоною Вранча. На основі виконаних досліджень можна припустити, що кореляційний взаємозв'язок між горизонтальними деформаціями визначеними за даними ГНСС i узагальненою сейсмічністю проявляється тільки у зонах субдукції, де $\epsilon$ інтенсивна сейсмоактивність $\mathrm{i}$ мають прояви постійні деформації земної кори. Це підтверджується проявом зон кореляцій, які розташовані вздовж однієї зі сторін активних розломів.

Ключові слова: горизонтальні деформації земної кори, перманентні ГНСС-станції, землетрус, взаємозв'язок сейсмічності та руху ГНСС-станцій

Received 03.02.2020 